\title{
Phosphoproteins regulated by heat stress in rice leaves
}

\author{
Xinhai Chen ${ }^{1,2 \dagger}$, Wenfeng Zhang ${ }^{1,2 \dagger}$, Baoqian Zhang ${ }^{2 \dagger}$, Jiechao Zhou ${ }^{2}$, Yongfei Wang ${ }^{2}$, Qiaobin Yang ${ }^{2}$, Yuqin Ke ${ }^{2}$ \\ and Huaqin $\mathrm{He}^{1,2,3^{*}}$
}

\begin{abstract}
Background: High temperature is a critical abiotic stress that reduces crop yield and quality. Rice (Oryza sativa L.) plants remodel their proteomes in response to high temperature stress. Moreover, phosphorylation is the most common form of protein post-translational modification (PTM). However, the differential expression of phosphoproteins induced by heat in rice remains unexplored.

Methods: Phosphoprotein in the leaves of rice under heat stress were displayed using two-dimensional electrophoresis (2-DE) and Pro-Q Diamond dye. Differentially expressed phosphoproteins were identified by MALDITOF-TOF-MS/MS and confirmed by Western blotting.

Results: Ten heat-phosphoproteins were identified from twelve protein spots, including ribulose bisphos-phate carboxylase large chain, 2-Cys peroxiredoxin BAS1, putative mRNA binding protein, Os01g0791600 protein, OSJNBa0076N16.12 protein, putative H(+)-transporting ATP synthase, ATP synthase subunit beta and three putative uncharacterized proteins. The identification of ATP synthase subunit beta was further validated by Western-blotting. Four phosphorylation site predictors were also used to predict the phosphorylation sites and the specific kinases for these 10 phosphoproteins.

Conclusion: Heat stress induced the dephosphorylation of RuBisCo and the phosphorylation of ATP- $\beta$, which decreased the activities of RuBisCo and ATP synthase. The observed dephosphorylation of the mRNA binding protein and 2-Cys peroxiredoxin may be involved in the transduction of heat-stress signaling, but the functional importance of other phosphoproteins, such as $\mathrm{H}^{+}$-ATPase, remains unknown.
\end{abstract}

\section{Background}

The inherent immobility of plants limits their abilities to avoid stress, requiring them to cope with abiotic stresses through innate defense mechanisms [1]. Some abiotic stresses, such as drought, salinity, extreme temperatures, chemical toxicity and oxidative stresses, are serious threats to agriculture and abiotic stresses have become the primary cause of crop loss worldwide, reducing average yields for most major crop plants by more than 50\% [2]. High temperature is one of the most important abiotic stresses that reduce crop yield and quality [3,4]. Rice production is likely to be affected severely by an increase in mean global temperature [5,6]. The overall global temperature has

\footnotetext{
* Correspondence: hehq3@yahoo.com.cn

+ Contributed equally

${ }^{1}$ Key Laboratory of Ministry of Education for Genetic, Breeding and Multiple Utilization of Crops, Fuzhou 350002, China

Full list of author information is available at the end of the article
}

steadily increased in recent decades due to rapid increases in atmospheric greenhouse gas concentrations $[7,8]$. The average global temperature has increased by $0.6^{\circ} \mathrm{C}$ in the 20th century and is expected to continue to rise $1.4-5.8^{\circ} \mathrm{C}$ by the end of this century $[9,10]$. Understanding the mechanisms by which rice respond to heat stress would facilitate the development of heat-tolerant cultivars with improved productivity in a warmer future climate.

Several physiological mechanism of rice plants for heat tolerance had been identified, including the selectively upregulated of Rubisco activase large isoform, the increase of multiple enzymes of the Calvin Cycle, a fall in Ferredoxin$\mathrm{NADP}(\mathrm{H})$ oxidoreductase (FNR) and a consistent increase in expression of a thiamine biosynthesis protein (THI1) [11]. Rice plants can remodel their proteomes in response to high temperature stress. Lee et al. [8] found that HSPs and energy- and metabolism-associated proteins were the major proteins affected by a high temperature of $42^{\circ} \mathrm{C}$ in
C Biomed Central 
leaves. In another study, lignification-related proteins were regulated by high temperature, and distinct proteins related to protection were up-regulated at different high temperatures, indicating that different strategies were adopted at different levels of high temperature: the higher the temperature, the greater the involvement of the protection machineries [6].

Given the importance of protein phosphorylation in the regulation of cellular signaling, a major goal of current proteomic efforts is the identification of phosphoproteins in higher organisms [12]. Phosphorylated proteins have been identified on a large scale in rice treated with various hormones [13], under high salinity stress [14] and under drought stress[12]. However, studies of protein phosphorylation induced by heat in rice have been limited.

Phosphoproteins are typically detected by one of three approaches. Proteins may be labeled with either inorganic phosphate $\left({ }^{32} \mathrm{Pi}\right)$ in vivo or $\gamma-\left({ }^{32} \mathrm{P}\right)$-ATP in vitro [15]. However, $\gamma-\left({ }^{32} \mathrm{P}\right)$-ATP-labeling in vitro may result in the false-positive identification of phosphoproteins, and $\left({ }^{32} \mathrm{P}\right)$-radiolabeling in vivo may induce radiation damage to cultured cells or tissues [16]. Phosphorylated amino acids can also be detected by antibodies specific for phosphotyrosine, phosphothreonine, or phosphoserine [17], but this approach is often time-consuming and costly. Another technology for detecting phosphoproteins is Pro-Q Diamond phosphoprotein gel stain, which allows direct, in-gel detection of phosphate groups attached to tyrosine, serine or threonine residues. Using Pro-Q Diamond dye, Jin et al. [18] observed 19 phosphorylated proteins in blood monocytes, and Chitteti and Peng [19] investigated dynamic changes in the phosphoproteome of Arabidopsis cotyledon during cell dedifferentiation.

In this study, we used two-dimensional gel electrophoresis (2-DE) followed by Pro-Q diamond dye and tandom MS to investigate differential regulation of rice phosphoproteins during heat stress.

\section{Results}

\section{Pro-Q diamond staining of phosphoproteins}

Total proteins extracted from the leaves of rice in response to heat stress were separated by 2-DE and stained with Pro-Q Diamond dye. Overall 9 gel were analyzed, for each treatment in triplicates. More than 300 protein spots could be detected on each gel within a $\mathrm{p} I$ range of 3-10 and with relative molecular masses of 14$80 \mathrm{kDa}$ (Figure 1). However, the majority of the visible phosphoproteins in the gel had a relatively low $\mathrm{p} I$ of 3-7 and high MW of 30-60 KDa (Additional file 1, Figure S1). Chitteti and Peng (2007) also found that rice root phosphoproteins stained with Pro-Q Diamond dye had low $\mathrm{p} I$ values. Furthermore, Pro-Q Diamond dye stain intensity is not proportional to protein concentration [14]. Therefore, in this study, we focused on the phosphorylated and dephosphorylated proteins and not the variability of phosphoproteins abundance in rice under heat stress.

\section{Specificity of Pro-Q diamond}

To confirm the specificity of the Pro-Q Diamond for rice phosphoproteins, proteins extracted from the leaves of rice under heat stress were treated with CIP and then stained with Pro-Q or Coomassie blue dye (Additional file 2, Figure S2). Little staining by the Pro-Q Diamond

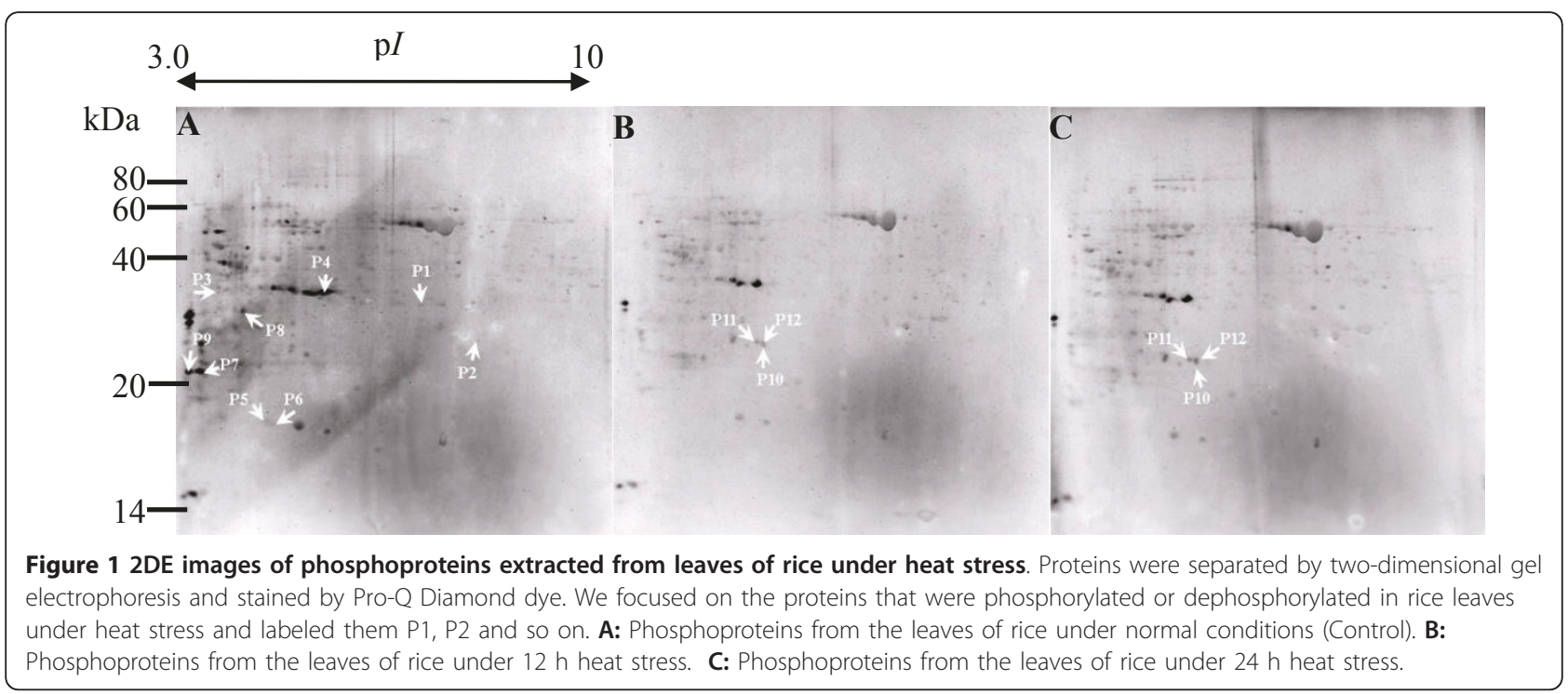


dye was visible on the CIP-treated gel (Additional file 2, Figure S2), while protein staining by R-250 was not affected by CIP treatment (Additional file 2, Figure S2). These results indicate that Pro-Q Diamond specifically binds rice phosphoproteins, which is consistent with the findings of Chetteti and Peng [14]. Therefore, Pro-Q dye was used to detect rice phosphoproteins.

\section{Identification of heat-stress phosphoproteins}

Using the Pro-Q Diamond stain, we constructed rice phosphoprotein maps after 12 and $24 \mathrm{~h}$ of high temperature stress at $42^{\circ} \mathrm{C}$ (Figure 1). To investigate the response of the putative phosphoproteins to heat stress, we compared the phosphoprotein maps and analyzed the differentially phosphorylated proteins with ProteinMaster software 6.0 (FortuneSun Corporation, China). Twelve protein spots were identified as heat-responsive phosphoproteins in all three replicates, nine of which were dephosphorylated and three of which were phosphorylated in the leaves of rice after $12 \mathrm{~h}$ and $24 \mathrm{~h}$ of high temperature stress (Figure 2).

These differentially phosphorylated protein spots were manually excised, digested with trypsin and identified with an ABI 4700 Proteomics Analyzer. The twelve

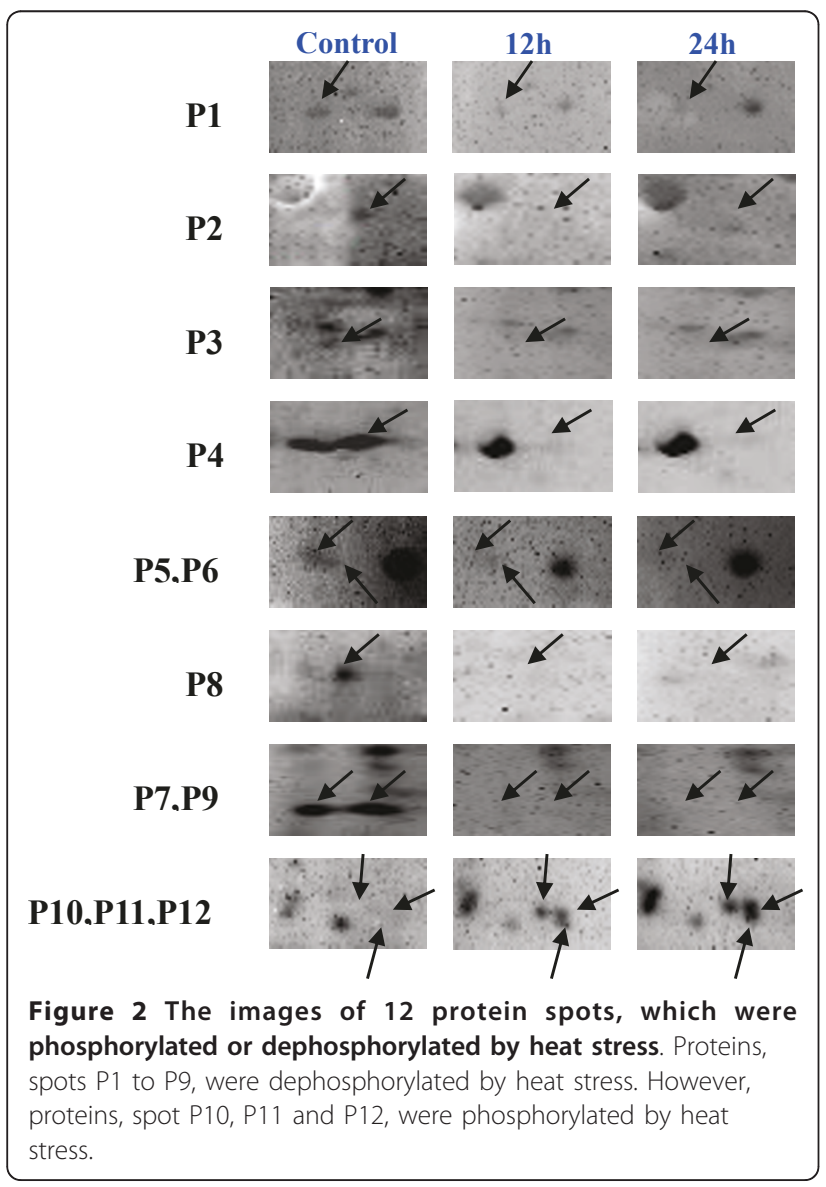

phosphoproteins were molecularly identified with high confidence (Table 1).

Ten of the differentially phosphorylated protein spots were identified as Rubisco large chain (spots P2, P5), 2Cys peroxiredoxin BAS1 (spots P3, P7), putative mRNA binding protein (spot P4), Os01g0791600 protein (spot P6), OSJNBa0076N16.12 protein (spot P8), putative $\mathrm{H}$ (+)-transporting ATP synthase (spot P9), chloroplastic ATP synthase subunit beta (spot P10) and Retrotransposon (spot P11) (Table 1). The remaining two protein spots were identified as putative uncharacterized proteins (spots P1, P12). That different spots, such as P3 and $\mathrm{P} 7$, identified as the same protein might be induced by co- or post-translational modifications.

\section{Immunoblotting analysis of ATP synthase subunit beta}

The protein identification was verified by immunoblotting analysis, using ATP- $\beta$ as a model protein. We first confirmed the specificity of the anti-ATP- $\beta$ antibody. The total proteins extracted from rice and Arabidopsis were immunoblotted with the anti-ATP- $\beta$ antibody; CIP was served as a negative control (Figure 3A). The parallel gels were stained with Coomassie blue (Figure 3B). Arabidopsis and rice proteins clearly reacted with the anti-ATP- $\beta$ antibody, but CIP did not (Figure 3), confirming the specificity of the anti-ATP synthase $\beta$ antibody.

The proteins extracted from rice leaves under heat stress were separated on $1 \mathrm{D}$ gels and 2-DE gels and then incubated with the anti-ATP- $\beta$ antibody. Two immunoreactive bands were detected in 1D gels (Figure $4 \mathrm{~A}$ ), and five ptroteins exhibited strong immunoreactivity in $2-\mathrm{DE}$ gels (Figure $4 \mathrm{E})$. The rice ATP- $\beta$ may have undergone co-or post-translational modifications that changed its $\mathrm{p} I$ and/or MW [20]. Alternatively, ATP- $\beta$ may have diverse isoforms in the rice leaves. Riego et al. [21] have found six isoforms of ATP- $\beta$ in barley and these six isoforms, which differed in their degrees of phosphorylation.

\section{Prediction of protein phosphorylation site}

Phosphorylation site predictors are an important complement to the experimental characterization of protein phosphorylation. All 12 phosphosproteins detected by Pro-Q dye were also predicted to be phosphoproteins by prediction tools (Table 2). The two Rubisco large chains (spots P2 and P5) were predicted to be phosphorylated at Serine-221 and Serine-228 by Ataxia-telangiectasia mutated (ATM) kinase. Serine-32 and serine-35 of 2Cys peroxiredoxin are potentially phosphorylated by Casein kinase I (CKI), cGMP-dependent protein kinase (PKG) and protein kinase $\mathrm{C}$ (PKC) delta. The putative mRNA binding protein regulated by heat could be a substrate of PKC and phosphorylated at threonine-59. 
Table 1 Twelve phosphoproteins in leaves of rice were identified by MALDI-TOF-TOF-MS/MS.

\begin{tabular}{|c|c|c|c|c|c|c|c|}
\hline $\begin{array}{l}\text { Spot } \\
\text { No. }\end{array}$ & $\begin{array}{l}\text { Accession } \\
\text { no. }\end{array}$ & $\begin{array}{c}\text { Theoretical } \\
\mathrm{Mr}(\mathrm{kDa}) / \\
\mathrm{pl}\end{array}$ & $\begin{array}{l}\text { Observed } \\
\text { Mr (kDa) }\end{array}$ & $\begin{array}{c}\text { No. of } \\
\text { Peptides }\end{array}$ & $\begin{array}{l}\text { Coverage } \\
(\%)\end{array}$ & Putative Protein & $\begin{array}{l}\text { Regulated by } \\
\text { heat }\end{array}$ \\
\hline P1 & B8AXZ6 & $8.74 / 38.6$ & 36.7 & 9 & 32 & Putative uncharacterized protein & $\mathrm{DP}$ \\
\hline P2 & D3W4H3 & $7.00 / 26.5$ & 25.4 & 7 & 27 & $\begin{array}{c}\text { Ribulose bisphosphate carboxylase large } \\
\text { chain }\end{array}$ & $\mathrm{DP}$ \\
\hline P3 & Q6ER94 & $5.67 / 28.3$ & 37.3 & 4 & 21 & 2-Cys peroxiredoxin BAS1, chloroplastic & DP \\
\hline P4 & Q8GTK8 & $7.68 / 41.2$ & 38.1 & 8 & 26 & mRNA binding protein & $\mathrm{DP}$ \\
\hline P5 & Q5K3B1 & $6.23 / 53.3$ & 18.2 & 15 & 23 & $\begin{array}{c}\text { Ribulose bisphosphate carboxylase large } \\
\text { chain }\end{array}$ & $\mathrm{DP}$ \\
\hline P6 & C7IWD0 & $4.92 / 41.9$ & 18.1 & 10 & 26 & Os01g0791600 protein & DP \\
\hline P7 & Q6ER94 & $5.67 / 28.3$ & 22.5 & 5 & 30 & 2-Cys peroxiredoxin BAS1, chloroplastic & $\mathrm{DP}$ \\
\hline P8 & Q7X7H3 & $6.75 / 39.8$ & 32.6 & 6 & 22 & OSJNBa0076N16.12 protein & DP \\
\hline P9 & Q6Z8K7 & $4.98 / 26.2$ & 22.4 & 4 & 25 & $\mathrm{H}(+)$-transporting ATP synthase & DP \\
\hline P10 & Q6ENG7 & $5.38 / 53.9$ & 27.8 & 7 & 22 & ATP synthase subunit beta, chloroplastic & $\mathrm{P}$ \\
\hline P11 & Q94GY1 & $5.64 / 22.8$ & 28.7 & 8 & 35 & Retrotransposon, centromere-specific & $P$ \\
\hline P12 & A2YJU3 & $9.75 / 11.9$ & 28.2 & 4 & 53 & Putative uncharacterized protein & $P$ \\
\hline
\end{tabular}

The protein spot numbers are given in Figure 1. Protein accession are from the Uniprot database http://www.uniprot.org/. DP: Dephosphorylated by heat stress; P: Phosphorylated by heat stress. The same below.

Kinasephos predicted that spot P6 can be phosphorylated at Serine- 165 by cell division control protein 2 (cdc2) and cyclin-dependent kinase (CDK). Serine-414 of ATP synthase subunit beta could be phosphorylated by casein kinase II or casein kinase I. The prediction tools also revealed that $\mathrm{H}^{+}$-ATPase may be phosphorylated at Serine- 16 by the kinase of $\mathrm{cdc} 2$ and CDK (Table 2).

\section{Gene ontology (GO) analysis}

Gene ontology analyses were performed for the 12 phosphoproteins to understand the biological processes and molecular functions involved in the rice heat stress response. Analysis of the biological processes revealed that three of the 12 variable phosphoproteins are

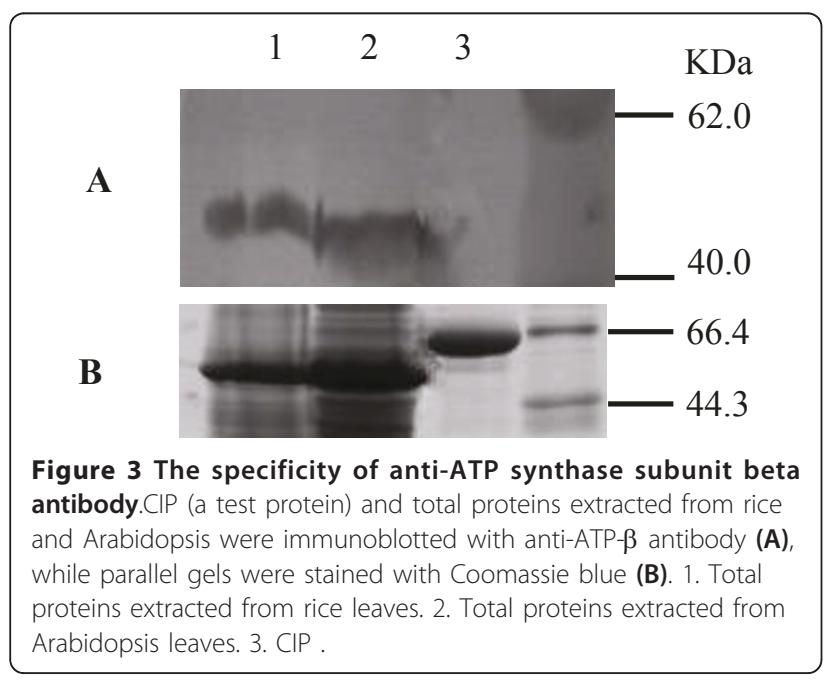

involved in the Calvin cycle, two are part of hydrogen peroxide catabolism, two participate in ATP synthesiscoupled proton transport, one is involved in microtubule-based movement, and one was involved in cellular metabolic processes while the others are unknown (Table 3).

\section{Discussion}

Twelve protein spots that exhibited altered phosphorylation in response to heat stress were identified by tandem mass spectrometry (Figure 1 and Table 1). RuBisCo is well known for its involvement in plant photorespiration (PR). In vitro phosphorylation of both the small and the large subunits of RuBisCo has been reported in spinach chloroplasts and rice $[22,23]$. Meanwhile, RuBisCo activity declines with dephosphorylation [22]. Thus, heat stress is likely to induce dephosphorylation of RuBisCo, resulting in the decrease of its activity.

Peroxiredoxins are a family of enzymes that catalyze the transfer of electrons from sulfhydryl residues to peroxides and are ubiquitously distributed among all organisms [24]. Peroxiredoxins have diverse functions in cellular defense-signaling pathways [25], and 2-Cys peroxiredoxin plays direct roles in cellular-signaling events [25-27]. Although its functional significance is unclear, heat-induced dephosphorylation of 2-Cys peroxiredoxin may be involved in the transduction of cellular-signaling. Previous studies have provided strong in vivo and in vitro evidence that mRNA-binding proteins translocate to ribosomes and associate with mRNA to stabilize the mRNA, facilitating its translation or degradation $[28,29]$. Park et al. [30] found that the RNA encoding a small RNA-binding protein was involved in abiotic stress 


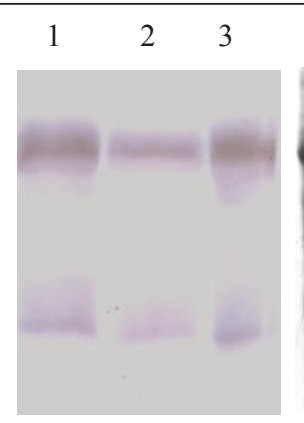

A

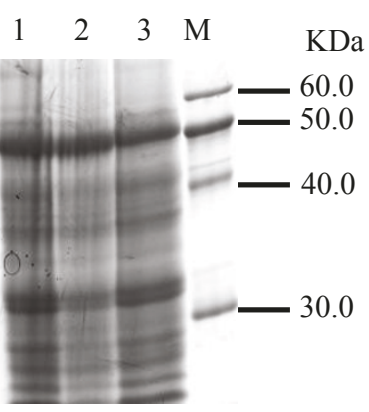

B

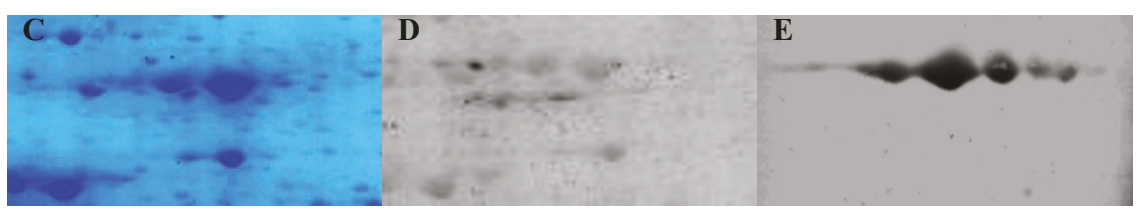

Figure 4 The first-dimensional and second-dimensional immunoblotting analysis of ATP- $\beta$ in leaves of rice under heat stress. The proteins extracted from leaves of rice under heat stress were separated in 1D and 2-DE gels, transferred to an NC membrane, and then incubated with anti-ATP- $\beta$ antibody. A: Proteins on the 1D gel were probed with an anti-ATP- $\beta$ antibody. B: Proteins on the 1D gel were visualized by Coomassie blue staining. C: Proteins on the 2-DE gel were visualized by Coomassie blue staining. D: Proteins on the 2-DE gel were visualized by Pro-Q Diamond staining. E: Proteins on the 2-DE gel were probed by anti-ATP- $\beta$ antibody. 1: Proteins extracted from the leaves of rice under $24 \mathrm{~h}$ heat stress. 2: Proteins extracted from the leaves of rice under $12 \mathrm{~h}$ heat stress. 3: Proteins extracted from the leaves of rice under normal conditions (Control). M: Marker.

signaling. Moreover, ectopic over-expression of a glycine-rich RNA binding protein imparted high temperature stress tolerance to wild type yeast cells, suggesting that glycine-rich RNA binding protein probably binds and stabilizes stress-inducible transcripts under heat stress conditions [31]. mRNA binding proteins have been reported to be phosphorylated in the mammalian cell [32]. However, we previously found that the mRNA binding protein is an ABA-induced dephosphorylation protein [16], consistent with this study. Dephosphorylation of the mRNA binding protein may be involved in heat-stress signaling and may function to stabilize the heat-stress transcripts.

The phosphorylation of ATP- $\beta$ in rice leaves under heat stress was confirmed by Pro-Q staining and western-blotting. The ATP- $\beta$ is phosphorylated by casein kinase II [33]. The 14-3-3 proteins, which contain a casein kinase II phosphorylation motif [34], associated with the ATP synthases in a phosphorylation-dependent manner, remarkably depressing ATP synthases activity [35]. A reduction in ATP synthases activity has also been observed when rice leaves were exposed to heat stress [8]. Thus, Heat stress reduces ATP synthase activity in rice by phosphorylating ATP synthases.

However, another type of ATP synthase, putative $\mathrm{H}$ (+)-transporting ATP synthase (spot P9), was dephosphorylated in rice under heat stress. $\mathrm{H}(+)$-transporting ATP synthase $\left(\mathrm{H}^{+}\right.$-ATPase $)$in the plant plasma membrane acts as a primary transporter by pumping protons out of the cell, thereby creating $\mathrm{pH}$ and electrical potential differences across the plasmalemma [36]. The $\mathrm{H}^{+}$-ATPase is involved in salinity tolerance [37], but the functional importance of $\mathrm{H}^{+}$-ATPase dephosphorylation is unclear.

\section{Conclusion}

In this study, ten differentially expressed phosphoproteins in rice leaves in response to heat stress were found. Heat stress induced the dephosphorylation of RuBisCo and the phosphorylation of ATP- $\beta$, decreasing the activities of RuBisCo and ATP synthase. The observed dephosphorylation of the mRNA binding protein and 2-Cys peroxiredoxin may be involved in the transduction of heat-stress signaling, but the functional importance of other phosphoproteins, such as $\mathrm{H}^{+}$-ATPase, remains unknown. Future work will validate or identify the functional importance of these heat-induced phosphoproteins.

\section{Methods}

\section{Plant growth and heat stress treatment}

Rice (Oryza sativa L. cv. Nipponbare) were germinated at $30^{\circ} \mathrm{C}$ for $48 \mathrm{~h}$. The germinated seedlings were grown in a greenhouse at $28^{\circ} \mathrm{C} \pm 2^{\circ} \mathrm{C}$ during the day and $22^{\circ} \mathrm{C} \pm 2^{\circ} \mathrm{C}$ at night under natural light conditions (14 h light/10 h darkness period). Seedlings were grown in nutrient solution according to $\mathrm{Li}$ et al. [38]. For high temperature 
Table 2 The phosphorylation sites of 12 phosphoproteins were predicted by using different tools

\begin{tabular}{|c|c|c|c|c|c|}
\hline Accession no. & Putative protein & $\begin{array}{l}\text { Regulated } \\
\text { by heat }\end{array}$ & Phosphorylation site & Tools & Kinases \\
\hline B8AXZ6 & Putative uncharacterized protein & $\mathrm{DP}$ & Serine-33 & $\begin{array}{l}\text { Disphos } \\
\text { Kinasephos } \\
\text { NetphosK } \\
\text { Scansite }\end{array}$ & $\begin{array}{l}\text { cdc2, cdk5, } \\
\text { ATM, MAPK }\end{array}$ \\
\hline D3W4H3 & RuBisCo large chain & DP & Serine-221 & Kinasephos & ATM \\
\hline Q5K3B1 & RuBisCo large chain & DP & Serine-228 & Kinasephos & ATM \\
\hline Q6ER94 & 2-Cys peroxiredoxin BAS1, chloroplastic & DP & Serine-32 & $\begin{array}{l}\text { Disphos } \\
\text { Kinasephos } \\
\text { Scansite }\end{array}$ & $\begin{array}{l}\text { CKI } \\
\text { 14-3-3 Mode1 }\end{array}$ \\
\hline Q6ER94 & 2-Cys peroxiredoxin BAS1, chloroplastic & $\mathrm{DP}$ & Serine-35 & $\begin{array}{l}\text { Disphos } \\
\text { Kinasephos } \\
\text { Scansite }\end{array}$ & $\begin{array}{l}\text { PKG } \\
\text { PKC delta }\end{array}$ \\
\hline Q8GTK8 & Putative mRNA binding protein & $\mathrm{DP}$ & Threonine-59 & $\begin{array}{l}\text { Kinasephos } \\
\text { NetphosK }\end{array}$ & PKC \\
\hline C7IWD0 & Os01g0791600 protein & $\mathrm{DP}$ & Serine-165 & Kinasephos & $\mathrm{cdc} 2, \mathrm{CDK}$ \\
\hline Q7X7H3 & OSJNBa0076N16.12 protein & DP & Serine-18 & $\begin{array}{l}\text { Disphos } \\
\text { Kinasephos } \\
\text { Netphos2 } \\
\text { Scansite }\end{array}$ & $\begin{array}{l}\text { cdc2, MAPK } \\
\text { cdc2 } \\
\text { Casein kinase }\end{array}$ \\
\hline Q7X7H3 & OSJNBa0076N16.12 protein & DP & Serine-27 & $\begin{array}{l}\text { Disphos } \\
\text { Kinasephos } \\
\text { Netphos2 } \\
\text { Scansite }\end{array}$ & Erk1 kinase \\
\hline Q6Z8K7 & Putative $\mathrm{H}(+)$-transporting ATP synthase & $\mathrm{DP}$ & Serine-16 & $\begin{array}{l}\text { Disphos } \\
\text { Kinasephos }\end{array}$ & $\mathrm{cdc} 2, \mathrm{CDK}$ \\
\hline Q6ENG7 & ATP synthase subunit beta, chloroplastic & $P$ & Serine-414 & $\begin{array}{l}\text { Kinasephos } \\
\text { Scansite }\end{array}$ & $\begin{array}{l}\text { Casein kinase I, } \\
\text { Casein kinase } 2\end{array}$ \\
\hline Q94GY1 & Retrotransposon, putative, centromere-specifi & P & Serine-127 & $\begin{array}{l}\text { Kinasephos } \\
\text { Disphos }\end{array}$ & cdc2, ATM, IKK \\
\hline A2YJU3 & Putative uncharacterized protein & $P$ & Serine-21 & $\begin{array}{l}\text { Disphos } \\
\text { Kinasephos } \\
\text { NetphosK }\end{array}$ & PKG, PKC \\
\hline
\end{tabular}

Phosphorylation site: The same phosphorylation site was predicted by different tools.

treatments, three-week-old rice seedlings were exposed to $42^{\circ} \mathrm{C}$ (Treatment) or $28^{\circ} \mathrm{C}$ (Control) for $12 \mathrm{~h}$ and $24 \mathrm{~h}$ [8]. Immediately after treatment, rice leaves were sampled and stored at $-80^{\circ} \mathrm{C}$.

\section{Two-Dimensional electrophoresis}

Total protein extracts were prepared from fresh leaves according to $\mathrm{He}$ and $\mathrm{Li}$ [16] with some modifications. Briefly, frozen rice leaf tissue was finely ground in liquid nitrogen and suspended in icecold $10 \% \mathrm{w} / \mathrm{v}$ TCA in acetone containing $0.2 \% \mathrm{w} / \mathrm{v} \mathrm{DTT}$, incubated at $-20^{\circ} \mathrm{C}$ overnight and centrifuged at 30,000 g for 25 min at $4^{\circ} \mathrm{C}$. The pellets were collected and resuspended in $0.2 \% \mathrm{w} / \mathrm{v}$ DTT in acetone, incubated at $-20^{\circ} \mathrm{C}$ for 4 $\mathrm{h}$ and centrifuged for $25 \mathrm{~min}$ at $30,000 \mathrm{~g}$. This procedure was repeated three times and the pellets were lyophilized. The resulting samples were solubilized in lysis buffer (7 M urea, $2 \mathrm{M}$ thiourea, 4\% CHAPS, 2\% Ampholine $\mathrm{pH} 3.5-10,65 \mathrm{mM}$ DTT and $0.5 \mathrm{mM}$ PMSF) and then centrifuged at $30,000 \mathrm{~g}$ for $25 \mathrm{~min}$ at $4^{\circ} \mathrm{C}$. The supernatants were collected and subjected to two-dimensional electrophoresis (2-DE). Protein concentrations were measured according to Bradford [39]. Focusing of the first dimension took place on a Protean IEF Cell (Bio-Rad, USA). After isoelectric focusing, the PH 3-10 IPG (17 cm, nonlinear) strips were immediately equilibrated in equilibration buffer (50 $\mathrm{mM}$ Tris- $\mathrm{HCl}, \mathrm{pH} 8.8,6 \mathrm{M}$ urea, 30\% glycerol, $2 \%$ SDS, $1 \%$ DTT and $0.002 \%$ bromophenol blue) and then placed directly onto $12 \%$ polyacrylamide-SDS slab gels. The gels were then stained by Pro-Q dye and Coomassie blue dye; parallel gels were probed by immunoblotting using a ATP-specific antibody.

\section{Detection of phosphoproteins}

The 2-DE gels were stained with Pro-Q Diamond dye (Molecular Probes, USA) to detect phosphoproteins according to the manufacturer's instructions. 2-DE gels were fixed in solution (50\% methanol, $10 \%$ acetic acid) and washed with distilled water three times. The gels were then stained with Pro-Q Diamond dye. After destaining (20\% acetonitrile, $50 \mathrm{mM}$ sodium acetate, $\mathrm{pH}$ 
Table 3 Functional categorization of 12 phosphoproteins in leaves of rice under heat stress.

\begin{tabular}{|c|c|c|c|c|}
\hline $\begin{array}{l}\text { Spot } \\
\text { no. }\end{array}$ & Putative Protein & Cellular component & Biological process & Molecular function \\
\hline P1 & $\begin{array}{c}\text { Putative } \\
\text { uncharacterized } \\
\text { protein }\end{array}$ & NA & NA & transferase activity, transferring glycosyl groups \\
\hline P2 & $\begin{array}{c}\text { Ribulose } \\
\text { bisphosphate } \\
\text { carboxylase large } \\
\text { chain }\end{array}$ & $\begin{array}{l}\text { plastid } \\
\text { Chloroplast }\end{array}$ & $\begin{array}{c}\text { Calvin cycle, } \\
\text { Carbon dioxide fixation, } \\
\text { Photosynthesis }\end{array}$ & $\begin{array}{l}\text { ribulose-bisphosphate carboxylase activity, magnesium } \\
\text { ion binding }\end{array}$ \\
\hline P3 & $\begin{array}{l}\text { 2-Cys peroxiredoxin } \\
\text { BAS1, chloroplastic }\end{array}$ & Chloroplast, plastid & $\begin{array}{c}\text { cell redox homeostasis, } \\
\text { hydrogen peroxide catabolic } \\
\text { process }\end{array}$ & $\begin{array}{l}\text { Antioxidant } \\
\text { Oxidoreductase } \\
\text { Peroxidase }\end{array}$ \\
\hline P4 & $\begin{array}{l}\text { Putative } \mathrm{mRNA} \\
\text { binding protein }\end{array}$ & NA & Cellular metabolic process & catalytic activity, coenzyme binding \\
\hline P5 & $\begin{array}{c}\text { Ribulose } \\
\text { bisphosphate } \\
\text { carboxylase large } \\
\text { chain }\end{array}$ & Chloroplast & Calvin cycle, Photosynthesis & $\begin{array}{l}\text { ribulose-bisphosphate carboxylase activity, } \\
\text { monooxygenase activity }\end{array}$ \\
\hline P6 & $\begin{array}{l}\text { Os01g0791600 } \\
\text { protein }\end{array}$ & photosystem & $\begin{array}{l}\text { carbon utilization by fixation of } \\
\text { carbon dioxide, photosynthetic } \\
\text { electron transport chain }\end{array}$ & $\begin{array}{c}\text { ribulose-bisphosphate carboxylase activity, } \mathrm{NADH} \\
\text { dehydrogenase (ubiquinone) activity }\end{array}$ \\
\hline P7 & $\begin{array}{l}\text { 2-Cys peroxiredoxin } \\
\text { BAS1, chloroplastic }\end{array}$ & Chloroplast, plastid & $\begin{array}{c}\text { cell redox homeostasis, } \\
\text { hydrogen peroxide catabolic } \\
\text { process }\end{array}$ & $\begin{array}{l}\text { Antioxidant } \\
\text { Oxidoreductase } \\
\text { Peroxidase }\end{array}$ \\
\hline P8 & $\begin{array}{l}\text { OSJNBa0076N16.12 } \\
\text { protein }\end{array}$ & NA & NA & phosphatase activity \\
\hline P9 & $\begin{array}{l}\text { Putative H } \\
\text { (+)-transporting } \\
\text { ATP synthase }\end{array}$ & plasma membrane & $\begin{array}{l}\text { ATP synthesis coupled proton } \\
\text { transport }\end{array}$ & $\begin{array}{c}\text { hydrogen ion transporting ATP synthase activity, } \\
\text { rotational mechanism }\end{array}$ \\
\hline P10 & $\begin{array}{l}\text { ATP synthase } \\
\text { subunit beta, } \\
\text { chloroplastic }\end{array}$ & $\begin{array}{l}\text { chloroplast thylakoid } \\
\text { membrane, proton- } \\
\text { transporting ATP synthase } \\
\text { complex, catalytic core } F(1)\end{array}$ & $\begin{array}{l}\text { plasma membrane ATP synthesis } \\
\text { coupled proton transport }\end{array}$ & $\begin{array}{l}\text { ATP binding, hydrogen ion transporting ATP synthase } \\
\text { activity, } \\
\text { rotational mechanism, hydrogen-exporting ATPase } \\
\text { activity, phosphorylative mechanism, proton- } \\
\text { transporting ATPase activity, rotational mechanism }\end{array}$ \\
\hline P11 & $\begin{array}{l}\text { Retrotransposon, } \\
\text { putative, } \\
\text { centromere-specifi }\end{array}$ & NA & NA & NA \\
\hline P12 & $\begin{array}{c}\text { Putative } \\
\text { uncharacterized } \\
\text { protein }\end{array}$ & NA & NA & NA \\
\hline
\end{tabular}

4.0), the gels were scanned with a TYPHOON TRIO+ scanner (GE Corporation, USA).

\section{Specificity of Pro-Q Diamond}

To validate the specificity of Pro-Q Diamond for rice phosphoproteins, protein samples were prepared from rice leaves in extraction buffer $(50 \mathrm{mM}$ Tris- $\mathrm{HCl} \mathrm{pH}$ 8.4, $100 \mathrm{mM} \mathrm{NaCl}, 1 \mathrm{mM} \mathrm{MgCl}_{2}$ and $1 \mathrm{mM} \mathrm{DTT}$ ) excluding phosphatase inhibitors and incubated with Calf intestinal phosphatase (Promega Corporation, USA) or phosphatase buffer alone at $37^{\circ} \mathrm{C}$ for $2 \mathrm{~h}$. The protein samples were then separated by SDS-PAGE, stained with Pro-Q Diamond or Coomassie blue dye, and scanned with a TYPHOON TRIO+ scanner.

\section{Analysis of 2-DE Gels}

Images of 2-DE gels stained by Pro-Q dye and Coomassie blue dye were analyzed with ProteinMaster 6.0 software (FortuneSun Corporation, China). After spot detection and background subtraction (lowest on boundary mode), the 2-DE gels were aligned and matched, and the spot volumes were quantitatively determined (total spot volume normalization mode). The spots of interest were excised from the Coomassie blue dye stained gels with a scalpel and stored at $-4^{\circ} \mathrm{C}$ in destaining solution (50\% CAN, $100 \mathrm{mM} \mathrm{NH} \mathrm{NHCO}_{3}$ ) for subsequent MS analysis.

\section{Mass spectrometry analysis and database searches}

Protein spots were digested with sequencing-grade trypsin (Promega) as described previously [16]. The resulting peptides were desalted with C18 ZipTips (Millipore), mixed with $5 \mathrm{mg} / \mathrm{ml}$ alpha-cyanocinnamic acid in 70\% acetonitrile and $0.1 \%$ trifluoroacetic acid, and spotted onto a MALDI sample plate. Mass spectra were acquired on a MALDI TOF/TOF mass spectrometer 
(4700 Proteomics Analyzer, Applied Biosystems) in both the MS and the MS/MS modes. Data were analyzed using MASCOT software (Matrix Science, UK). NCBI $\mathrm{nr}$ or Swiss-Prot was selected as the database. Typical search parameters were as follows: mass tolerance, 0.5 $\mathrm{Da}$; missed cleavages, 2; enzyme, trypsin; fixed modifications, carbamidomethylation; variable modification, Oxidation (M); taxonomy, Oryza Sativa. For a match to be considered a valid identification, a confidence interval (C. I.) greater than $95 \%$ was required $[12,16]$.

\section{Immunoblot analysis of ATP- $\beta$}

Samples containing equivalent amount $(30 \mu \mathrm{g})$ of protein were separated by SDS-PAGE on a $12.5 \%$ acrylamide gel (1-D). All samples were heated for $10 \mathrm{~min}$ in boiling water, cooled to room temperature and subjected to electrophoresis at a constant voltage of $100 \mathrm{~V}$ until the dye front reached the bottom of the gel. The gels were then probed by immunoblotting using ATP- $\beta$ specific antibody; parallel gels were stained with Coomassie blue stain.

The proteins in the 1D and 2-DE gels were transferred onto an NC membrane (Bio-Rad Corporation, USA) and immunoblotted with anti-ATP- $\beta$ antibody as described previously $[12,16]$. Membranes were blocked with $5 \%$ (w/ v) BSA in TBST (20 mM Tris- $\mathrm{HCl}, \mathrm{pH} 7.5,150 \mathrm{mM} \mathrm{NaCl}$, $0.05 \%(\mathrm{v} / \mathrm{v})$ Tween-20) for 1 hour at room temperature and then incubated with rabbit anti-ATP- $\beta$ (AS05085, Agrisera) at a 1:1000 dilution for $3 \mathrm{~h}$ at room temperature. After being washed with TBST, membranes were incubated with goat anti-rabbit IgG conjugated with horseradish peroxidase at a 1:2,000 dilution for 1 hour. The membrane was then washed with TBST and developed with substrate (3,3'-diaminobenzidine) until optimum color developed.

\section{Prediction of phosphorylation site}

Four recently published methods were selected to predict the phosphorylation site: Disphos [40], Kinasephos [41], NetphosK [42], Scansite [43]. We selected the $A$. thaliana option of Eukaryotes in Disphos for prediction. KinasePhos was used with $100 \%$ prediction specificity option, and no specific kinase was set. All the phosphoproteins were analyzed with the NetPhosK server without a filtering method, and a threshold of 0.7 was used to judge whether a site was predicted to be phosphorylated. Scansite was run by searching all motifs and the "high stringency level" setting was selected. Using these tools, we focused on obtaining the collective phosphorylation site(s) or distributive kinase(s), which is more reliable than using one method with one protein.

\section{Gene ontology (GO) annotation of phosphoproteins}

Functional categorization of proteins was performed according to the GO rules using the gene ontology tools at http://www.agbase.msstate.edu. Three independent sets of ontologies were used to describe a gene product, the biological process, the molecular function and the cellular compartment [12].

\section{Additional material}

Additional file 1: Supplementary Figure 1. 2-DE images of proteins extracted from leaves of rice under heat stress.

Additional file 2: Supplementary Figure 2. The specificity of Pro-Q Diamond dye for rice phosphoproteins.

\section{Abbreviations}

HSPs: Heat shock proteins; ATP- $\beta$ : ATP synthase subunit beta; RuBisCo: Ribulose bisphosphate carboxylase; CIP: Calf intestinal phosphatase; ATM: Ataxia-telangiectasia mutated kinase; CKI: Casein kinase I; PKG: CGMPdependent protein kinase; PKC: protein kinase C; cdc2: cell division control protein 2; CDK: Cyclin-dependent kinase; NC: Nitrocellulose.

\section{Acknowledgements}

We thank the anonymous referees whose constructive comments were very helpful in improving the quality of this work. This work was supported by the National Natural Science Foundation of China (No. 31070402), a grant from Education Department of Fujian (No. JA10103) and the Key Program of Ecology, Fujian, China (No. 0608507 and No. 0b08b005). HQH is in receipt of a grant for the postdoctor position in FAFU.

\section{Author details}

${ }^{1}$ Key Laboratory of Ministry of Education for Genetic, Breeding and Multiple Utilization of Crops, Fuzhou 350002, China. ${ }^{2}$ College of Life Sciences, Fujian Agriculture and Forestry University, Fuzhou 350002, China. ${ }^{3}$ College of Horticulture, Fujian Agriculture and Forestry University, Fuzhou 350002, China.

\section{Authors' contributions}

$\mathrm{HQH}$ conceived of the study, designed experiments, analyzed data and wrote the manuscript. XHC designed and carried out experiments and wrote the manuscript, WFZ carried out the 2D-gels and wrote the manuscript. BQZ conducted the 1D gel experiment. JCZ performed the Pro-Q experiments. YFW analyzed protein data. QBY participated in the data analysis. YQK coordinated the study. All authors read and approved the final manuscript.

\section{Competing interests}

The authors declare that they have no competing interests.

Received: 18 May 2011 Accepted: 30 June 2011 Published: 30 June 2011

\section{References}

1. Kuiper PJC: Adaptation mechanism of green plants to environmental stress. The role of plant sterols and the phosphatidyln linolenoyl cascade in the functioning of plants and the response of plants to global climate change. In Ann NY Acad Sci Edited by: Csermely P 1998, 851:209-215, Stress of Life: From Molecules to Man.

2. Swindell WR, Huebner M, Weber AP: Transcriptional profiling of Arabidopsis heat shock proteins and transcription factors reveals extensive overlap between heat and non-heat stress response pathways. BMC Genomics 2007, 8:125.

3. Peng S, Huang J, Sheehy JE, Visperas RM: Rice yields decline with higher night temperature from global warming. Proc Natl Acad Sci USA 2004, 101(27):9971-9975. 
4. Lin S, Chang M, Tsai Y, Lur H: Proteomic analysis of the expression of proteins related to rice quality during caryopsis development and the effect of high temperature on expression. Proteomics 2005, 5(8):2140-2156.

5. Grover A, Chandramouli A, Agarwal S, Katiyar-Agarwal S, Agarwal M, Sahi C: Transgenic rice for tolerance against abiotic stresses. In Rice Improvement in the Genomic Era. Edited by: Datta SK. Hawarth Press USA; 2009:237-267.

6. Han F, Chen H, Li X, Yang M, Liu G, Shen S: A comparative proteomic analysis of rice seedlings under various high-temperature stresses. Biochim Biophys Acta 2009, 1794(11):1625-1634.

7. Easterling DR, Horton B, Jones PD, Peterson TC: Maximum and minimum temperature trends for the globe. Science 1997, 277:364-367.

8. Lee D, Ahsan NB, Lee S, Kang K, Bahk J, Lee I, Lee B: A proteomic approach in analyzing heat-responsive proteins in rice leaves. Proteomics 2007, 7(18):3369-3383.

9. Albritton DL, Derwent RG, Isaksen ISA, Lal M, Wuebbles DJ: Trace gas radiative forcing indices. In Climate change 1994 - radiative forcing of climate change and an evaluation of the IPCC IS92 Emission Scenarios. Edited by: Houghton JT, Meiro Filho LG, Bruce JP, Lee H, Callander BA, Haites EF, Harris N, Maskell K. Cambridge University Press, Cambridge; 1994:205-246.

10. Houghton JT, Ding Y, Griggs DJ, Noguer M, van der Linden PJ, Dai X, Maskell K, Johnson CA: Climate change 2001: The scientific basis. Cambridge UK: Cambridge University Press; 2001, 1-20.

11. Scafaro AP, Haynes PA, Atwell BJ: Physiological and molecular changes in Oryza meridionalis $\mathrm{Ng}$., a heat-tolerant species of wild rice. J Exp Bot 2010, 61(1):191-202.

12. Ke Y, Han G, He H, Li J: Differential regulation of proteins and phosphoproteins in rice under drought stress. Biochem Bioph Res Co 2009, 379(1):133-138.

13. Khan M, Takasaki H, Komatsu S: Comprehensive phosphoproteome analysis in Rice and identification of phosphoproteins responsive to different hormones/stresses. J Proteome Res 2005, 4(5):1592-1599.

14. Chitteti BR, Peng Z: Proteome and phosphoproteome differential expression under salinity stress in rice (Oryza sativa L.) roots. J Proteome Res 2007, 6(5):1718-1727.

15. Delom F, Chevet E: Phosphoprotein analysis: from proteins to proteomes. Proteome sci 2006, 4:15.

16. He H, Li J: Proteomic analysis of phosphoproteins regulated by abscisic acid in rice leaves. Biochem Bioph Res Co 2008, 371(4):883-888.

17. Kaufmann $H$, Bailey JE, Fussenegger M: Use of antibodies for detection of phosphorylated proteins separated by two-dimensional gel electrophoresis. Proteomics 2001, 1(2):194-199.

18. Jin M, Diaz PT, Bourgeois T, Eng C, Marsh CB, Wu HM: Two-dimensional gel proteome reference map of blood monocytes. Proteome sci 2006, 4:16.

19. Chitteti BR, Peng Z: Proteome and phosphoproteome dynamic change during cell dedifferentiation in Arabidopsis. Proteomics 2007, 7(9):1473-1500.

20. Ahsan N, Komatsu S: Comparative analyses of the proteomes of leaves and flowers at various stages of development reveal organ specific functional differentiation of proteins in soybean. Proteomics 2009, 9(21):4889-4907.

21. Riego GD, Casano LM, Martín M, Sabater B: Multiple phosphorylation sites in the beta subunit of thylakoid ATP synthase. Photosynth Res 2006, 89(1):11-18

22. Kaul R, Saluja D, Sachar RC: Phosphorylation of small subunit plays a crucial role in the regulation of RuBPCase in moss and spinach. FEBS 1986, 209:63-70.

23. Foyer $\mathrm{CH}$ : Stromal protein phosphorylation in spinach (Spinacia oleracea) chloroplasts. Biochem J 1985, 231(1):97-103.

24. Baler M, Dietz KJ: The plant 2-Cys peroxiredoxin BAS1 is a nuclearencoded chloroplast protein: its expressional regulation, phylogenetic origin, and implications for its specific physiological function in plants. Plant J 1997, 12(1):179-190.

25. Jang H, Chi Y, Park S, Lee S, Lee J, Park J, Moon J, Lee Y, Kim S, Lee K, Lee S: Structural and functional regulation of eukaryotic 2-Cys peroxiredoxins including the plant ones in cellular defense signaling mechanisms against oxidative stress. Physiol Plantarum 2006, 126:549-559.

26. Kang SW, Changa TS, Lee TH, Kima ES, Yue DY, Rhee SG: Cytosolic peroxiredoxin attenuates the activation of Jnk and p38 but potentiates that of Erk in Hela cells stimulated with tumor necrosis factor-alpha. J Biol Chem 2004, 279(4):2535-2543.

27. Choi MH, Lee IK, Kim GW, Kim BU, Han YH, Yu DY, Park HS, Kim KY, Lee JS, Choi C, Bae YS, Lee BI, Rhee SG, Kang SW: Regulation of PDGF signalling and vascular remodelling by peroxiredoxin II. Nature 2005, 435(7040):347-353

28. Thomas JB, Robert E, Sharwood RG, Silva LM, David BS: The RNA-binding proteins CSP41a and CSP41b may regulate transcription and translation of chloroplast-encoded RNAs in Arabidopsis. Plant Mol Biol 2009, 69(5):541-552.

29. Menon B, Peegel $H$, Menon K: Evidence for the association of luteinizing hormone receptor $\mathrm{mRNA}$-binding protein with the translating ribosomes during receptor downregulation. Biochim Biophys Acta 2009, 1793(11):1787-1794

30. Park HY, Kang IS, Han JS, Lee CH, An G, Moon YH: OsDEG10 encoding a small RNA-binding protein is involved in abiotic stress signaling. Biochem Bioph Res Co 2009, 380(3):597-602.

31. Sahi C, Garwal M, Ingh A, Grover A: Molecular characterization of a novel isoform of rice (Oryza sativa L.) glycine rich-RNA binding protein and evidence for its involvement in high temperature stress response. Plant Sci 2007, 173:144-155.

32. Waskiewicz AJ, Johnson JC, Penn B, Mahalingam M, Kimball SR, Cooper JA Phosphorylation of the cap-binding protein eukaryotic translation initiation factor 4E by protein kinase Mnk1 in vivo. Mol Cellular Bio 1999, 19(3):1871-1880

33. Kanekatsu M, Saito H, Motohashi K, Hisabori T: The beta subunit of chloroplast ATP synthase (CF0CF1-ATPase) is phosphorylated by casein kinase II. Biochem Mol Biol Int 1998, 46(1):99-105.

34. Kanekatsu M, Ezumi A, Nakamura T, Ohtsuki K: Chloroplast Ribonucleoproteins (RNPs) as Phosphate Acceptors for Casein Kinase II: Purification by ssDNA-Cellulose Column Chromatography. Plant Cell Physiol 1995, 36(8):1649-1656.

35. Bunney TD, van Walraven HS, de Boer AH: 14-3-3 protein is a regulator of the mitochondrial and chloroplast ATP synthase. Proc Natl Acad Sci USA 2001, 98(7):4249-4254.

36. Michelet $\mathrm{B}$, Boutry $\mathrm{M}$ : The Plasma Membrane $\mathrm{H}^{+}$-ATPase (a highly regulated enzyme with multiple physiological functions). Plant Physio 1995, 108(1):1-6.

37. Niu X, Narasimhan M, Salzman R, Bressan RA, Hasegawa PM: $\mathrm{NaCl}$ regulation of plasma membrane $\mathrm{H}^{+}$-ATPase gene expression in a glycophyte and a halophyte. Plant Physiol 1993, 103(3):713-718.

38. Li XJ, Yang MF, Chen H, Qu LQ, Chen F, Shen SH: Abscisic acid pretreatment enhances salt tolerance of rice seedlings: proteomic evidence. Biochim Biophys Acta 2010, 1804(4):929-40.

39. Bradford MM: A rapid and sensitive method for the quantitation of microgram quantities of protein utilizing the principle of protein-dye binding. Anal Biochem 1976, 72:248-254.

40. lakoucheva LM, Radivojac P, Brown CJ, O'Connor TR, Sikes JG, Obradovic Z, Dunker AK: The importance of intrinsic disorder for protein phosphorylation. Nucleic Acids Res 2004, 32(3):1037-1049.

41. Huang HD, Lee TY, Tzeng SW, Horng JT: KinasePhos: a web tool for identifying protein kinase-specific phosphorylation sites. Nucleic Acids Res 2005, 33:W226-W229.

42. Blom N, Sicheritz-Ponten T, Gupta R, Gammeltoft S, Brunak S: Prediction of post-translational glycosylation and phosphorylation of proteins from the amino acid sequence. Proteomics 2004, 4(6):1633-1649.

43. Obenauer JC, Cantley LC, Yaffe MB: Scansite 2.0: Proteome-wide prediction of cell signaling interactions using short sequence motifs. Nucleic Acids Res 2003, 31(13):3635-3641.

doi:10.1186/1477-5956-9-37

Cite this article as: Chen et al:: Phosphoproteins regulated by heat stress in rice leaves. Proteome Science 2011 9:37. 